\title{
OFFENSES PRINCIPLES AND A LIMITATION FOR DISINFORMATION VIA THE INTERNET IN INDONESIA
}

\author{
Vidya Prahassacitta \\ Business Law Program, Law Department Faculty of Humanities, \\ Bina Nusantara University Jakarta \\ JI. Kemanggisan Ilir III No.45, Palmerah, Jakarta Barat, \\ Daerah Khusus Ibukota Jakarta, 11480 \\ e-mail: vidya.prahassacitta@binus.ac.id
}

\begin{abstract}
Actors utilize the internet to spread disinformation. The content might be irritated the public but does not cause direct distribution to public order. Article 14 and Article 15 of Law No. 1 of 1946 on Criminal Law Regulation prohibit the publication of disinformation that causes the distribution to public order. However, the implementation of the legislation shows that the panel of judges punish the actor who publishes disinformation without considering the impact of that disinformation on society. Therefore, the purpose of this research is to criticize the limitation of disinformation distribution through the internet under offenses principles. The principles are used to analyze the relevancy and limitation of criminalization in article 14 and article 15. By using document research with the statute, case, and conceptual approaches, it is concluded that the intervention of criminal law may be justified to protect public order, but the intervention shall be limited which strict requirements.
\end{abstract}

Keywords: disinformation, internet, offenses principles

\section{A. Introduction}

Indonesia faces a critical problem when false, fake, and inaccurate information is spread massively and becomes viral on the internet., The Ministry of Communication and Information of the Republic of Indonesia verified 1.527 false, fake, and inaccurate information on Covid-19 spread through 3.110 contents from January 2020 until April 2021. Internet platforms like Facebook, Instagram, Twitter, and YouTube have taken down 2.687 contents while the authorities are still processing the rest. Ministry of Communication and Information Republic of Indonesia reported 113 unlawful contents to Indonesia National Police for further investigation procedure. ${ }^{1}$

False, fake, and inaccurate information is also known as a hoax. Merriam Webster Online Dictionary defines hoax as "to trick into believing or accepting as genuine something false and often preposterous". 2

1 Ministry of Communication and Information Technology Republic of Indonesia, "Penanganan Sebaran Isu Hoaks Covid-19 Jumat (16/04/2021),",https://www.kominfo.go.id/content/detail/33916/penanganansebaran-isu-hoaks-covid-19-jumat-16042021/0/infografis (accessed 17 April 2021).

2 Merriam Webster Online Dictionary, "Hoax," https://www.merriam-webster.com/dictionary/hoax (accessed 17 April 2021) 
The Hoax has a broad term, it includes both harmful and false information which is created for entertainment purposes such as a meme, parody, or satire. On the other hand, some hoaxes are harmful and illegal, such as disinformation, which is defined as false, fake, and inaccurate information that is intentionally created and distributed through the internet to harm others. ${ }^{3}$ Merriam Webster Online Dictionary defines disinformation as "false information deliberately and often covertly spread to influence public opinion or obscure the truth." " Clair Wadle defines disinformation as content that covers false, fake, lies information that intentionally designs and distribute via the internet with the purpose to harm people or the public. Disinformation is part of information disorder. Disinformation is different from fake news. Disinformation, not a press product because does not produce according to the journalistic code of ethics. ${ }^{5}$

Unfortunately, Law No. 11 of 2008 as amended by Law No. 19 of 2016 concerning Information and Electronic Transaction (Information and Electronic Transaction Law) does not regulate the prohibition of disinformation content. Like Minister of Communication and Information Republic of Indonesia Regulation Number 5 of 2020 concerning Private Electronic System Operator which regulates prohibited electronicinformation. In practice, the Ministry of Communication and Information Republic of Indonesia categorizes disinformation as prohibited electronic information because it contains illegal content or harmful content that disturbs public order. However, it does not clearly define the boundaries between disinformation that serves as part of illegal or harmful content.

Disinformation is part of the prohibited electronic information. Article 14 and Article 15 Law No.1 of 1946 concerning Criminal Regulation (Law No. 1 the Year 1946) ban the distribution of disinformation. This provision is controversial because some argue that the prohibition against freedom of expression. First, Article 14 and Article 15 of Law No. 1 of 1946 originate from the colonial period. The regulation adopts from Article 171 Wetboek van strafrecht voor Nederlandsch-Indië which only apply in the Netherlands colony. ${ }^{6}$

There are previous researches related to criminal law and the distribution of false, fake, and inaccurate information. Yanto Irianto has researched hoax regulations under the Indonesian legal system and Islamic law. ${ }^{7}$ Mompang L Panggabean in his

3 Claire Wardle, Information Disorder (London: FirstDraft, 2019). P. 15.

4 Merriam Webster Online Dictionary, “Disinformation,” accessed 17 April 2021, https://www.merriamwebster.com/dictionary/disinformation?utm_campaign=sd\&utm_medium=serp\&utm_source=jsonld. (Accessed 17 April 2021)

$5 \quad$ Claire Wardle, Information Disorder. P. 15.

6 Han Bing Siong, Verhandelingen Van Het Koninklijk Instituut Voor Taal-, Land- En Volkenkunde An Outline of the Recent History of Indonesian Criminal Law (Berlin: Springer-Science+ Business Media, B. V., 1961). P. 23; and Moeljatno, Kejahatan-Kejahatan Terhadap Ketertiban Umum (Open Bare Orde) (Jakarta: Bina Aksara, 1984). P. 132-141.

$7 \quad$ Yanto Irianto, "Enforcement Of Criminal Law In False News (Hoax) Management According To Law No. 11 In 2008 That Has Been Amended To Be Law No.19 Of 2016 Concerning Electronic Information And Transactions In Islamic Law And Positive Laws," The 5th PROCEEDING “ Legal Reconstruction in Indonesia (2019).P.208- 
research concludes that Article 14 and Article 15 of Law No. 1 of 1946 are not suitable to enforce the distribution of disinformation, subsequently, a new formulation is required for Indonesia's current situation. ${ }^{8}$ Both previous kinds of research discussed Indonesian legislation that regulated the distributions of disinformation. However, both researchers do not discuss the limitation of criminalization of distribution of disinformation, especially via the internet. This research aims to criticize the limitation of the distribution of disinformation through the internet using offenses principles.

The research starts with a discussion about offenses principles as theoretical background to analyze the criminalization of the distribution of disinformation. Then, the researcher gives a critical review regarding the provision and the implementation problems on Article 14 and Article 15 of Law No. 1 of 1946. Next, the researcher analyses the limitations of the distribution of disinformation, mainly via the internet. In this part, first, the researcher refers to the international practice of the limitation of disinformation. In the second part, the researcher analyzes the limitation for the criminalization of disinformation using offenses principles. It is a recommendation to regulate the criminalization of the distribution of disinformation.

\section{B. Research Method}

The method of this research is legal research as well as systematic study regarding legal regulation, legal principle, legal concept, legal theory, legal doctrine, court verdict, law institution which covers issues or problems that may also be a combination of all those aspects. ${ }^{9}$ The study does not limit to applicable law but also ideas and perception which is a part of the aims and functions of law. Researchers use legal documents and non-legal documents including previous research related to criminal law, freedom of expression, and disinformation as well as other available data. ${ }^{10}$ The result of this research is to give critical recommendations and guidelines for law practice.

Three approaches were used in this research. First, the statue approach, the researcher reviewed and analyzed the polemic between philosophical values on an act and research problems. Second, the case approach to review the legislation implementation, to analyze the implication and recommend legislation process. ${ }^{11}$ The researcher analyzes several court decisions that were indicted and sentenced using Article 14 or 15 of Law No. 1 of 1946 to describe problems in implementing Article 14 or 15 of Law No. 1 of 1946 . Last, the conceptual approach, the legal doctrine was used to analyze the research problems. ${ }^{12}$

8 Mompang L Panggabean, "Handling of Hoax News According to Law Number 1 of 1946," International Journal of Advanced Science and Technology 29, No. 08 (2020). P. 1275-1287.

9 A Yaqin, Legal Research and Writing (Malaysia: Lexis Nexis Grup, 2011). P.3-4.

10 R Singleton and B C Straits, Approaches to Social Research (Oxford: Oxford University Press, 2018 ). P. 326.

11 Jonaedi Efendi and Johnny Ibrahim, Metode Penelitian Hukum: Normatif Dan Empiris (Depok: Prenada Media, 2018), https://books.google.co.id/books?id=50ZeDwAAQBAJ. 
Researchers reviewed and analyzed regulation-related disinformation, especially in article 14 and article 15 Law No. 1 the Year 1946 , determining whether this regulation is suitable under freedom of expression value by using offenses principle.

\section{Discussions}

\section{Offenses Principles}

Feinberg describes the offense as all types of the miscellany of disliked mental states. An action considers as an offense if fulfills three criteria. First when one suffers a disliked state. Second, when one attributes that state to be wrongful conducts of another. Last, when one resents the others for his role in causing one to be in that state. ${ }^{13}$ The seriousness of offenses determined by a balancing test which consists of four criteria, the seriousness of the offense, how widespread it and social value. ${ }^{14}$

The offense principles use to limit criminalization. In this article, criminalization is described as state intervention that declares a behavior as an offense. According to A.P. Simester and Andreas von Hirsch, the offense principles gave the limitation for the state to criminalize intolerant behavior and potentially harmful in the public sphere. 15 In offenses principles, the argument for state intervention is not only the behavior is immoral but also to protect other's people or public interests.
Simester and von Hirsch limit the offense's behavior. Not all nuisance and offensive behaviors are offenses. Only the behavior that shows intolerance, unrespectful to others, and tends to break the law can be categorized as offense behavior. ${ }^{16}$ This type of behavior puts the other person in an unpleasant situation. Subsequently, the other person may also be potentially losing their emotional control. Ignoring this offensive behavior will create more serious and harmful behavior.

According to Simester dan, von Hirsch offense principles also require harm as the consequences of the offense behavior. ${ }^{17}$ Offenses principles dealing with indirect harm. The psychological harm and eventual harm are part of this indirect harm. Psychological harm is the psychological condition of the person being disturbed by other's offenses behavior. Eventual harm is dealing with a value loss from a violation that happens in the long term. If we ignore and do not address this offense behavior it will become more serious behavior and can cause harm to others. ${ }^{18}$

\section{Critics Towards Article 14 and Article 15 of Law No. 1 of 1946 and Its Implementations}

Criminalization of disinformation distribution is first regulated in Article 171 of Wetboek van strafrecht voor Nederlandsch-

13 R Cohen-Almagor, Speech, Media and Ethics: The Limits of Free Expression (New York: Palgrave Macmillan UK, 2001). P. 9.

14 Joel Feinberg, The Moral Limits of the Criminal Law: Volume 2: Offense to Others (New York: Oxford Univeristy Press, 2006). Hlm. 185.

15 A. P. Simester and Andrew von Hirsch, "Rethinking the Offense Principle," Legal Theory 8 (2002). P. 278.

16 Andrew von Hirsch, "The Offence Principle in Criminal Law: Affront to Sensibility or Wrongdoing?," King's Law Journal 11, no. 1 (2000): 78-89. P. 82-83.

17 Simester and Hirsch, "Rethinking the Offense Principle." P. 273-275.

18 von Hirsch, "The Offence Principle in Criminal Law: Affront to Sensibility or Wrongdoing?” P. 78-80. 
Indië. Based on concordantie principle in Article 75 of Regerings Reglement and Article 131 of Indiche Staatsregeling, Crimineel Wetboek voor het Koninglijk was applied in the colony of Netherlands which was adjusted with the colony's situation and conditions. ${ }^{19}$ Article 171 Wetboek van strafrecht voor Nederlandsch-Indië is one of that adjustment. The provision punishes a person who intentionally creates a riot by distributing disinformation. ${ }^{20}$ In 1940, Nederlandsch-Indië military Government issued Verordening Miliitair Gezag No. 18/Dvo/VII A-3 dated 21 May 1940 and Verordening Miliitair Gezag No. 19/Dvo./ VII A-3 dated 8 June 1940. Both regulations amended the Provision 171 of Wetboek van strafrecht voor Nederlandsch-Indië. ${ }^{21}$

Netherland only applied this penal policy in their colony. Other than in NederlandschIndië, this policy is also applied in Suriname. Article 190 of Wetboek van Strafrecht voor Suriname, punishes a person who spread disinformation that potentially disturbs public order. During Suriname's independence in 1975 , this provision is maintained. Crimineel Wetboek voor het Koninglijk Holland does not have similar article. In Article 142 of Crimineel Wetboek voor het Koninglijk Holland, Netherlands only criminalizes false alarm action.

When Indonesia was gaining its independence, Article 171 of Wetboek van strafrecht voor Nederlandsch-Indië was invoked and replaced by Article 14 and Article 15 of Law No. 1 of 1946. However, those articles were still preserved the same norm as in Article 171 Wetboek van strafrecht voor Nederlandsch-Indië. Law No. 1 of 1946 complements the Penal Code. ${ }^{22}$ Then in Draft Penal Code 2019, this norm and formulation were still preserved in Articles 262 and Article 263.

Article 14 and Article 15 Law No. 1 of 1946 requires a publication that provides false or wrong information to the public, ${ }^{23}$ if the information is proven to be one hundred percent false. Law No. 1 of 1946 official explanation stated that if a person publishes correct information, then the person shall not be punished. Article 14(1), 14(2), 15 of Law No. 1 of 1946 have a different formulation. Article 14(1) of Law No. 1 of 1946 prohibits a person who intentionally distributes disinformation to create chaos. Then, Article 14(2) of Law No. 1 of 1946 punishes a person whose recklessness distributes disinformation which has the potential to create chaos. Article 15 of Law No. 1 of 1946, punishes a person whose negligence distributes uncertainty or incomplete information that potentially causes chaos.

The true information element in Article 14 and Article 15 of Law No. 1 of 1946 shall be a highlight. The problem of this element is who shall authorize that information as Hindia Belanda (Weltevreden: Balai-poestaka, 1921). Article 171.

21 Moeljatno, Kejahatan-Kejahatan Terhadap Ketertiban Umum (Open Bare Orde). P. 132 and 141; Siong, Verhandelingen Van Het Koninklijk Instituut Voor Taal-, Land- En Volkenkunde An Outline of the Recent History of Indonesian Criminal Law. P. 23.

23 Moeljatno, Kejahatan-Kejahatan Terhadap Ketertiban Umum (Open Bare Orde). 
false or true. Each party has its version of the truth. on the other hand, only a part of the information is false or wrong. Some contain accurate information, and it is used to manipulate and convince internet users so they believe that information is based on accurate information. ${ }^{24}$ The person who intentionally spread this information and potentially creates chaos cannot be punished under Law No. 1 of 1946. In disinformation, only a part of the information is false or wrong. Some contain accurate information, and it is used to manipulate and convince internet users so they believe that information is based on accurate information. ${ }^{25}$ The person who intentionally spread this information and potentially creates chaos cannot be punished under Law No. 1 of 1946.

In 1990, South Jakarta District Court punish a journalist who publishes disinformation news using Article 14 paragraph (2) of Law No. 1 of 1946. Abdul Wahid a journalist and an editor of Ekonomi Berita Buana magazine publish an article with title "Banyak Makanan yang Dihasilkan Ternyata Mengandung Lemak Babi". He writes the article based on Tri Susanto research regarding forty types of food that contain lard. The article is based on several facts but the defendant using incorrect words, he should use the word "diragukan ("doubt") rather than "ternyata". Subsequently, food manufacture that produces the suspect product experienced a decrease in their sales. ${ }^{26}$
The court only considers the incorrect information without considering properly that the defendant's intention and the serious impact of the news on society. As a journalist, the defendant's main intention to publish news is to deliver information to the public. Not all information that in the news was wrong. The problem is the defendant chose incorrect words that caused a stir in the community. According to the official explanation of Articles 14 and 15 of Law No. 1 of 1946, the defendant shall not be punished if the information published contains accurate facts or information. Then the public reluctance to buy the suspect product that causes food manufacture to decrease in their sales also shall not justify the chaos that requires in Article 14 paragraph (2) of Law No. 1 of 1946.

The court maintains its judgment when cases of disinformation widely spread via the internet. Like in Balikpapan District Court Decision Number 255/Pid.Sus/2019/ PN.Bpp, a panel of Judges argues that the defendant Lisa Tri Ekawati is reckless because she, without checking the fact of the information, posted the disinformation message on her wall of Facebook account and forwarded the disinformation message to the WhatsApp Group. In this case, the defendant distributes the disinformation message regarding seven hundred ballots that arrived at Tanjung Priok port which were to be used to win particular presidential candidates during the 2018 general election.

24 Claire Wardle, Information Disorder.

25 Ibid.

26 Nyanda Fatmawati Octarina, Pidana Pemberitaan Media Sosial (Malang: Setara Press, 2018). P. 27 -28; and ARM and Indrawan, "Buntut Berita Lemak Babi," Tempo (Jakarta, 1990), https://majalah.tempo.co/read/ hukum/19384/memvonis-nama-lengkap. (17 April 2021). 
However, the panel of Judges does not consider that the defendant does not know and does not have any relation with the owner of the social media account that post previous disinformation messages. ${ }^{27}$ Then, the panel of judges failed to describe which society was being disadvantaged from that disinformation message.

Similar to Singkawang District Court Decision Number 216/Pid.Sus/2020/PN SKW, the defendant Eko Febriyansyah posted a picture with a false statement regarding the Covid-19 patient in Singkawang hospital on his Facebook. The panel of judges argues that the defendant is reckless because he creates and publishes a statement only based on his assumption and does not check the facts. Although the defendant purpose is only to alert people regarding the spread of the Covid-19 virus in Singkawang. In this decision, the public defined as 926 members of the defendant's friends in his Facebook. ${ }^{28}$ However, it is not in line with the chaos element described by the panel of judges as the cause of the defendant's statement that creates anxiety and commotion in Singkawang society.

In those court decisions, the court prioritizes false information rather than culpability and harm. Criminalization shall consider proportionality and subsidiarity principles. We shall evaluate the benefit and harm of the disinformation to publish the disinformation. Then, we also shall evaluate alternative procedures to deliver accurate information to the public. To a possible extent, sharing information shall be without potential harm. No person shall be liable to punishment if the person does not have an evil mind and the disinformation publication does no serious harm. Only disinformation that publishes with bad intention and causes serious harm to the public that shall be punished.

Next, those court decisions are unclear on what type of disinformation that is prohibited. Those relate to types of content and how the disinformation is delivered. Those three court decisions have different content disinformation start from consumer good, politic-related general election, to health. Article 14 and Article 15 of the Law No. 1 of 1946 are part of the offense against public order, and the disinformation must be related to public concern. Then, how the defendants present the disinformation that made public disturbed. Unfortunately, the panel of judges does not discuss and describe these issues.

\section{Limitation for Disinformation in International Practice}

In those court decisions, the defendants guilty if they spread information that contains false or fake information. This rise debate whether publishing disinformation to the public is protected or unprotected speech. International conventions and a free nation's practice give reference to the debate.

International conventions do not state clearly whether publication and distribution of disinformation are prohibited. The disinformation relates to freedom of expression which part of civil and political 
rights. Article 19 (3) International Covenant on Civil and Political Rights stated that national law shall limit the freedom of expression only to protect a person's reputation, public order, and national security. According to this provision, only defamation that part of disinformation that is prohibited. Then in the International Convention on Freedom of Information 1949, disinformation that disturbs world peace is prohibited. Disinformation is part of state propaganda that is distributed by the press to distribute and threatens the security of other countries. ${ }^{29}$ Both international conventions do not regulate the disinformation that disturbs public order.

The European Court of Human Rights provides guidelines for delivering false and inaccurate information in the public sphere. In Chauvy and others vs France, ${ }^{30}$ and in Perinçek $v$ Switzerland ${ }^{31}$ the court argues that the truth of history information or statement shall be protected only if that information or statement is built based on 'established historical fact'. In this case, the truth about a statement is important but the statement delivers under purpose and value that is protected by the European Convention on Human Rights. The speech shall protect another person's reputation, public order, national security, disclosure of confidential information, and shall prevent disorder or crime.

Then in several countries, harm as a cause of disinformation is required to limit the speech. The German Supreme Court is providing limitations for false publishing and inaccurate information in the public sphere which shall balance the public order from harm. In BVerfGE 90, 241 (1994) or Ausschwitz Lie' case $^{32}$ and BVerfGE 54, 2081 BvR 797/78 Böll-decision,,33 the supreme court argues that information about a false or inaccurate fact that harms others is not a protected speech. It does not deserve protection because the aims of that information do not promote public opinion. In the United States of America, harm towards other parties is required to criminalizing a speech. In 2012 United States Supreme Court on United States v Alverez decriminalized a provision in the Stolen Valor Act that prohibits a person to publish a false statement regarding a military medal because this statement does not cause harm. ${ }^{34}$

Singapore has different perfective which the harm does not main require to limitation a speech. In 2019 Singapore issued Protection

29 T McGonagle and Y Donders, The United Nations and Freedom of Expression and Information (Cambridge: Cambridge University Press, 2015). P.10-19.

30 Chauvy and Others vs France (2004) https://hudoc.echr.coe.int/fre\#\%7B\%22itemid\%22:(\%2200161861\%22)\%7D (Accessed 15 March 2021).

31 Perinçek v. Switzerland (2015) https://www.echr.coe.int/Documents/Press_Q_A_Perinçek_ENG.pdf (Accessed 15 March 2021).

32 BVerfGE 90, 241 (1994), https://law.utexas.edu/transnational/foreign-law-translations/german/case. php?id=621 (Accessed 15 March 2021).

33 BVerfGE 54, 2081 BvR 797/78 Böll-Decision (1980), https://law.utexas.edu/transnational/foreign-lawtranslations/german/case.php?id=642 (Accessed 15 March 2021).

34 Rahel Boghossian Louis W. Tompros, Richard A. Crudo, Alexis Pfeiffer, "The Constitutionality Of Criminalizing False Speech Made On Social Networking Sites In A Post- Alvarez, Social Media-Obsessed World," OctoHarvard Journal of Law \& Technology 31, no. 1 Fall (2017): 65-109. P. 68-69. 
from Online Falsehoods and Manipulation Act. In this legislation, Singapore criminalizes the person or corporation that fabricates, alternate, and distribute disinformation and the person or corporation that uses an inauthentic account or bot to distribute and to accelerate the disinformation communication. However, Singapore does not use criminal law as a priority. Singapore also introduces a correction direction. It is a government order for a person to correct or to clarify the statement. In all that provisions Singapore does not require harm to public order. The limitation is based on necessary or expedient principles stated in Singapore Constitution. ${ }^{35}$ The purpose of this limitation is to maintain neutrality communication among Singapore citizens, especially on the internet, by intervention in the communication.

The above analyses show that the prohibition of the spread of disinformation is justified with a clear threshold. The truth of information shall proportionally review with the negative impact of the disinformation. Limitations of disinformation based on a free nation's purpose and value that wants to be protected. In Germany and the United States of America political speech has more protected than other kinds of speech, therefore the limitation of disinformation related to political speech is looser, ${ }^{36}$ including the intervention of criminal law. This kind of situation deference in Singapore where the right of its citizen to deliver their opinion is an act of the government to serves society interest. ${ }^{37}$

\section{Limitations for Criminalization Using Offences Principles}

The intervention against the distribution of disinformation via the internet, in particular, is relevant because of its negative impact of the disinformation itself. The actor uses technology information and communication to distribute disinformation via the internet. Actors create disinformation and distribute it massively using the bot and fake accounts. On several occasions, the actor uses buzzer services and adversities to distribute disinformation content. ${ }^{38}$ The peril of disinformation is the snowball effects. It starts with cognitive bias, then produces post-truth and polarization in the society. The dangers of disinformation are showed on analyses of seven container ballot paper disinformation. During the general election year 2019, this disinformation spread massive and viral notions on social media and became trending topics. Analysis of that trending topic shows that it produces polarization in society. ${ }^{39}$ Although this disinformation does not indicate direct harm, it may incite chaos in a polarized society. Its

\footnotetext{
35 David Tan and Jessica Sijie Teng, "Fake News, Free Speech and Finding Constitutional Congruence," Singapore Academy of Law Journal 32, no. 1 (2020): 207-248.P. 210.

36 Victoria L. Killion, "The First Amendment: Categories of Speech," Freedom of Speech: Background, Issues and Regulations (2020): 1-5.

37 L. a. Thio, "Singapore: Regulating Political Speech and the Commitment 'to Build a Democratic Society," International Journal of Constitutional Law 1, no. 3 (2003): 516-524.

38 Samantha Bradshaw and Philip N Howard, The Global Disinformation Order 2019 Global Inventory of Organised Social Media Manipulation, University of Oxford, 2019. P. 10-19.

39 Ismail Fahmi, “Hoax 7 Kontainer:"Stop Hoax Mari Kawal Suara," https://pers.droneemprit.id/hoax-7kontainer-stop-hoax-mari-kawal-suara/. (Accessed 25 November 2020)
} 
causes psychological and eventual harm.

Three previous court decisions show that those kinds of disinformation may be irritated and nuisance public, but those actions shall not deserve punishment. Indonesia needs a new threshold to criminalize the distribution of disinformation via the internet. The offenses principles can be applied to limit the criminalization of the disinformation distribution- via the internet because these principles deali with irritation and nuisance action.

The criminalization using offenses principles should be approached with caution. Mediating principles require examination of whether the offense deserves to be criminalized. Simester and von Hirsch require four elements of mediating principles to limit criminalization to supervise the freedom of speech. The requirements are social tolerance, a constraint of ready avoidability, the requirement for immediacy, the importance of the public sphere. ${ }^{40}$

\subsection{The Intolerance Message and Presentation}

First, a society shall not allow offensive behavior, even though a member of a society does not realize that the behavior is harmful. Social tolerance is a tool to measure the objectivity of offensive behavior. ${ }^{41}$ How society reacts to this nuisance and offensive behavior, determines whether this offensive behavior deserves criminalization or not.

In disinformation, social tolerance relates to the content and presentation of the message. How the content is accepted by society depends on the value of the message itself. The situation and condition of a society is an important factor. In a plural and democratic society, the interaction is more complex, thus social tolerance should be more flexible. This type of society has a thicker skin than a traditional and homogeneous society. The presentation of the message relates to how the speaker delivers the message to the audience. When the speaker delivers the message with harsh, insulting words, aggressive and offensive style, it shows that the speaker does not tolerate the member of society. When a society rejects disinformation, it is a strong reason to criminalize the author/speech.

\subsection{Publish in Public Sphere that Accessible}

Next, a constraint of readily avoidability element relates with other elements, the importance of the public sphere. The avoidability against offensive behavior shall stay in the public area. ${ }^{42}$ The limitation of freedom of expression, be applied in a public area because when people exercise their freedom, they generate the risk to harm others, as well as disturbing public order and national security. It is only spoken in the public sphere that harms others or disturbs public order shall be criminalized.

The spread of disinformation via group chat in instant messaging applications such as WhatsApp, Line, or Telegram criminalization is more difficult to be traced.

40 A P Simester and Andreas von Hirsch, Crimes, Harms, and Wrongs: On the Principles of Criminalisation (Oxford: Hart Publishing, 2011). P. 123-134. 
Members of the group chat who dislike and become uncomfortable with disinformation can easily remove or block the member from a group.

However, it is different compared to the spread of disinformation via social media such as Facebook. Disinformation spreads widely because the speaker utilizes hashtags, bots, fake accounts, and algorithms. Several parties advertise the disinformation and engage buzzers to spread and incite conversation regarding the disinformation. ${ }^{43}$ In this case, even though a social media account is locked, disinformation can still appear on the social media wall. Social media users may report or block the account, but another advertisement, buzzer bot, or fake accounts are nevertheless may still appear on the social media wall. It is quite inevitable, therefore, the reason to criminalize this behavior is more important.

\subsection{Limited to intentionally action}

The last limitation is immediacy. The nuisance behavior conducts with mens rea or evil mind. ${ }^{44}$ When a nuisance behavior instigates to gain more followers in the public sphere, then it becomes a strong reason to criminalize the behavior. However, in the spread of disinformation through the internet this requirement shall be applied carefully. People have the right to express their opinion in the public sphere if that opinion is accepted in society. Including expressing their political view. On other hand, we must protect the internet so that it does not become propaganda that may disturb public order.

When disinformation spreads on the internet and becomes a trending topic, this phase still is yet to meet the requirement to be labeled as criminalization. However, when the trending topics lead to negative conversation such as producing polarization and hatred to other ethnicities, races, or religious groups in the society then it becomes a strong reason to criminalize the disinformation. It shows that disinformation has the potential to disturb public order. Not everyone can build a harmful conversation on the internet. Buzzers and public figures have this capability. Therefore, this requirement only relates to the speaker's capability to distribute disinformation on the internet.

In this case, criminalization only applies to the distribution of disinformation via the internet that is conducted intentionally. The defendant's purpose in publishing the disinformation is to disturb and manipulate other internet users. Then the defendant knows to expand the spread of disinformation and to build the internet user conversation using disinformation, so the disinformation becomes massive and viral that disturb and irritate the public.

In the end, offense principles limit the criminalization of distribution disinformation via the internet. This principle provides a threshold which disinformation that shall be enforced by criminal law and shall be

43 Rinaldi Camil, Natasha Hassan Attamimi, and Klara Esti, "Dibalik Fenomena Buzzer: Memahami Lanskap Industri Dan Pengaruh Buzzer Di Indonesia," Centre for Innovation Policy and Governance (2017): 1-28.; and Bradshaw and Howard, The Global Disinformation Order 2019 Global Inventory of Organised Social Media Manipulation. P. 10-16. Buzzer is a person or influencer that has the ability to build conversation in social media and the internet with a certain motive. Semester and von Hirsch, Crimes, Harms, and Wrongs: On the Principles of Criminalisation. 
enforced by administrative law, Information and Transaction Electronic Law.

\section{Closing}

The spread of disinformation via the internet is relevant to criminalization. The intervention of criminal law does not only criminalize harmful behavior but also prevents harm. ${ }^{45} \mathrm{~A}$ preemptive investigation might be required, but with clear and strict boundaries, so it will not violate the freedom of expression. Criminalization is limited to serious disinformation. Criminalization is only intended for a person who intentionally fabricates and distributes disinformation that contains aggressive and provocative words, which then irritates members of society. In this case, the suspect has the knowledge and skills to spread disinformation massively on the internet and also to start harmful conversations that carry the risk of creating public disorder.

The new formulation requires, especially in the draft of Criminal Code, Article 14 (1) of Law No. 1 of 1946 that only applies to a person who intentionally produces and distributes disinformation that creates direct harm. This provision can still be adopted in the draft of Criminal Code. However, Article 14 (2) and Article 15 of Law No. 1 of 1946 shall be revoked. The new formulation requires that criminalizing a person who intentionally fabricates and distributes disinformation with a potential risk of disturbing public order is lawful.

Alignment between the penal code and the Information and Electronic Transaction
Act is required to determine disinformation that categorizes as illegal content or harmful to public order. The only disinformation that fits with the offense principles threshold shall be classified as illegal content. Therefore, the internet intermediary has the right to take down the disinformation content, and law enforcement is obligated to investigate.

\section{Bibliography}

1. Ashworth, Andrew. Principles of Criminal Law. Principles of Criminal Law. 4th ed. (New York: Oxford University Press, 2003).

2. Balai-poestaka, Wetboek Vaan Strafrecht Voor Nederlandsch Indie Kitab OendangOendang Hoekoeman Bagi Hindia Belanda. (Weltevreden: Balai-poestaka, 1921).

3. Efendi, Jonaedi, and Johnny Ibrahim. Metode Penelitian Hukum: Normatif Dan Empiris. (Depok: Prenada Media, 2018).

4. Feinberg, Joel. The Moral Limits of the Criminal Law: Volume 2: Offense to Others. (New York: Oxford Univeristy Press, 2006).

5. Hamzah, Andi, Asas-Asas Hukum Pidana. (Jakarta: Rineka Clpta, 2005).

6. Princeton University Press, 1994).

7. Marzuki, P M, Penelitian Hukum. (Jakarta: Kencana, 2005).

8. McGonagle, $\mathrm{T}$, and $\mathrm{Y}$ Donders, The United Nations and Freedom of Expression and Information (Cambridge: Cambridge University Press, 2015)

9. Moeljatno, Kejahatan-Kejahatan Terhadap Ketertiban Umum (Open Bare Orde). (Jakarta: Bina Aksara, 1984).

10. Simester, A P, and Andreas von Hirsch, Crimes, Harms, and Wrongs: On the

11. Principles of Criminalisation. (Oxford: Hart Publishing, 2011).

12. Simester, A. P., and Andrew von Hirsch. "Rethinking the Offense Principle." Legal Theory 8 (2002): 269-295. 
13. Octarina, Nyanda Fatmawati, Pidana Pemberitaan Media Sosial (Malang: Setara Press, 2018).

14. Singleton, R, and B C Straits, Approaches to Social Research. (Oxford: Oxford University Press, 2018).

15. Siong, Han Bing, Verhandelingen Van Het Koninklijk Instituut Voor Taal-, LandEn Volkenkunde an Outline of the Recent History of Indonesian Criminal Law. (Berlin: Springer-Science+ Business Media, B. V., 1961).

16. Wardle, Claire, Information Disorder. (London: FirstDraft, 2019).

17. Yaqin, A, Legal Research, and Writing. (Malaysia: Lexis Nexis Grup, 2011).

18. von Hirsch, Andrew., "The Offence Principle in Criminal Law: Affront to Sensibility or Wrongdoing?" King's Law Journal 11, no. 1 (2000): 78-89.

19. Irianto, Yanto, "Enforcement of Criminal Law in False News (Hoax) Management According to Law No. 11 In 2008 That Has Been Amended To Be Law No.19 Of 2016 Concerning Electronic Information And Transactions In Islamic Law And Positive Laws." The 5 th PROCEEDING "Legal Reconstruction in Indonesia (2019): 208219.

20. Cohen-Almagor, R. Speech, Media and Ethics: The Limits of Free Expression. New York: Palgrave Macmillan UK, 2001.

21. Killion, Victoria L. "The First Amendment: Categories of Speech." Freedom of Speech: Background, Issues and Regulations (2020): 1-5.

22. Louis W. Tompros, Richard A, Crudo, Alexis Pfeiffer, Rahel Boghossian. "The Constitutionality Of Criminalizing False Speech Made On Social Networking Sites In A Post- Alvarez, Social MediaObsessed World." OctoHarvard Journal of Law \& Technology 31, no. 1 Fall (2017): 65-109.

23. Panggabean, Mompang L. "Handling of Hoax News According to Law Number 1 of 1946." International Journal of Advanced Science and Technology 29, no. 08 (2020): 1275-1287.

24. Tan, David, and Jessica Sijie Teng. "Fake News, Free Speech and Finding Constitutional Congruence." Singapore
Academy of Law Journal 32, no. 1 (2020): 207-248.

25. Thio, L. a. "Singapore: Regulating Political Speech and the Commitment 'to Build a Democratic Society." International Journal of Constitutional Law 1, no. 3 (2003): 516524.

26. Hirsch von, Andrew. "The Offence Principle in Criminal Law: Affront to Sensibility or Wrongdoing?" King's Law Journal 11, no. 1 (2000): 78-89.

27. Bradshaw, Samantha, and Philip N Howard. The Global Disinformation Order 2019 Global Inventory of Organised Social Media Manipulation. University of Oxford, 2019.

28. Camil, Rinaldi, Natasha Hassan Attamimi, and Klara Esti. "Dibalik Fenomena Buzzer: Memahami Lanskap Industri Dan Pengaruh Buzzer di Indonesia." Centre for Innovation Policy and Governance (2017): 1-28.

29. ARM and Indrawan, "Buntut Berita Lemak Babi." https://majalah.tempo.co/read/ hukum/19384/memvonis-nama-lengkap. (Accessed 17 April 2021)

30. Fahmi, Ismail, "Hoax 7 Kontainer:Stop Hoax Mari Kawal Suara." https://pers. droneemprit.id/hoax-7-kontainer-stophoax-mari-kawal-suara/. (Accessed 25 November 2020)

31. Merriam Webster Online Dictionary, "Hoax." https://www.merriam-webster. com/dictionary/hoax (Accessed 1 February 2020).

32. Merriam Webster Online Dictionary, "Disinformation.". https://www. merriam-webster.com/dictionary/ disinformation?utm_campaign=sd\&utm medium $=$ serp\&utm_source $=$ jsonld. (Accessed April 17, 2021)

33. Ministry of Communication and Information Technology Republic of Indonesia, "Penanganan Sebaran Isu Hoaks Covid-19 Jumat (16/04/2021)." https://www.kominfo.go.id/content/ detail/33916/penanganan-sebaranisu-hoaks-covid-19-jumat-16042021/0/ infografis. (Accessed 17 April 2021).

34. Balikpapan district court decision number 255/Pid.Sus/2019/PN.Bpp dated 21 October 2019. 
35. BVerfGE 54, 2081 BvR 797/78 BöllDecision (1980). https://law.utexas.edu/ transnational/foreign-law-translations/ german/case.php?id=642 (Accessed 15 March 2021)

36. BVerfGE 90, 241 (1994) ('Ausschwitz Lie' Case) (1994).

37. Chauvy and Others vs France (2004). https://hudoc.echr.coe.int/ fre\#\%7B\%22itemid \% 22: [ \%22001 -
61861\%22]\%7D (Accessed 15 March 2021);

38. Perinçek v. Switzerland (2015). https://www.echr.coe.int/Documents/ Press_Q_A_Perinçek_ENG.pdf (Accessed 15 March 2021)

39. Singkawang district court decision number 216/Pid.Sus/2020/PN SKW dated 19 November 2020. 


\section{Curriculum Vitae of the Author}

Vidya Prahassacitta, SH. M.H. is a lecturer and faculty member of the Department of Business Law, Faculty of Humanity, Binus University, Jakarta. Vidya is a licensed advocate from Peradi since 2010. She holds her bachelor of law and master of law degrees both from the Faculty of Law, University of Indonesia. Currently, Vidya is a PhD candidate from the Faculty of Law, University of Indonesia, major in Criminal law and Criminal Justice System. Her dissertation title is Indonesian criminal law policy in the distribution of disinformation through the internet. Vidya can be reached via the following email vidya.prahassacitta@binus.ac.id or phone +628119770576 